DOI https:/ /doi.org/10.32837/app.v0i66.705

УДК 323.22

О. В. Аліксійчук

orcid.org/0000-0002-7237-5800

аспірант кафедри парламентаризму та політичного менеджменту Національної академії державного управління при Президентові України

\title{
ОЦІНЮВАННЯ ЕФЕКТИВНОСТІ РЕГІОНАЛЬНОЇ СОЦІАЛЬНОЇ ПОЛІТИКИ: ТЕОРЕТИКО-МЕТОДОЛОГІЧНІ МОДЕЛІ
}

Соціальна політика держави є однією з найважливіших сфер публічної політики, оскільки в основу вироблення, формування та впровадження відповідних рішень закладається принцип соціальної рівності. Тому реалізація соціальної політики держави на регіональному рівні повинна передбачати не лише ефективне використання ресурсів, а й забезпечувати належний розподіл отриманих результатів. Актуалізується проблема у виробленні належної методології щодо оцінювання ефективності регіональної соціальної політики в Україні.

У своєму дослідженні ми поставили за мету розглянути особливості оцінювання регіональної соціальної політики із застосуванням сучасних методів оцінювання політик. Аналітичні методи займають важливе місце в методології політичного аналізу. Вони дозволяють вирішувати значно складніші завдання, забезпечуючи дослідника відповідним якісним інструментарієм. Щоб досягнути поставленої мети, ми ставимо такі завдання: розкрити можливості використання аналітичних моделей в оцінюванні ефективності політик; показати переваги застосування аналітичних моделей для ефективності прийнятих рішень у публічній сфері на прикладі реалізації соціальної політики в Україні.

Оцінювання ефективності регіональної соціальної політики в Україні завжди знаходиться в центрі уваги українських вчених. Огляд методології здебільшого розглядається в контексті порівняльного аналізу за окремими інтегральними індикаторами з метою прогнозування окремих процесів регіональної економіки (Герасимчук, 2001; Семів, 2004; Садова, 2008).

За результатами напрацювань вчених розроблено низку методологій, які використовуються для ідентифікації проблем соціальної політики, компаративного аналізу та оцінки реалізації соціальної політики за різними індикаторами (Іртищева, 2018). Проблема підвищення ефективності функціонування органів державної служби залишається наріжним каменем не лише у процесі забезпечення реформування державної служби, а й у процесі вироблення та реалізації публічної політики.

Нині більшість дослідників у сфері оцінювання ефективності соціальної політики використовують метод описової статистики для пояснення динаміки основних показників у соціальній сфері (Макарова, 2015). Це обмежує потенційні можливості для пояснення особливостей реалізації соціальної політики в регіонах України, оскільки статистичні показники виконують функцію зрізу стану справ. Натомість актуальним залишається оцінювання ефективності політик на основі витрачених ресурсів. Зарубіжні дослідники поряд з описовою статистикою використовують аналітичний метод Data Envelopment Analysis (DEA), який дозволяє оцінити ефективність певної політики крізь призму співвідношення витрачених ресурсів і отриманих результатів (Avkiran, 2011, с. 690-695).

Метод DEA використовується для оцінки ефективності прийняття рішень (Decision Making Units) у різних сферах публічної політики з різними входами (бюджетні витрати за певний період часу) та виходами (соціальна віддача від реалізації певної політики). В основу методу DEA покладено математичне моделювання з можливістю визначення ефективності або відносної ефективності прийнятих рішень. Дослідники вказували, що метод DEA може застосовуватися для виявлення джерел неефективності, оцінювання ефективності певних бюджетних (цільових) програм чи політик, створюючи зручний інструмент для перерозподілу ресурсів (Golany, 1989, с. 240-246). Однак з початку публікації першої статті про методику DEA (Charnes, 1981) метод зазнав суттєвої еволюції й став у науково-дослідній спільноті одним із 
найбільш застосовуваних методів для оцінки ефективності програм і публічних політик.

Звичайна модель DEA базувалася на припущені, що вхідні дані конкретного періоду реалізації певних рішень витрачаються на отримання певних результатів того ж періоду реалізації певної програми чи політики (Charnes, 1994). Однак згодом вчені помітили, що класична модель аналізу DEA частково оцінює ефективність прийнятих рішень, оскільки певні програми або політики досягають результату протягом наступних кількох періодів. Це можна описати як оцінювання ефективності з певним відставанням у часі.

Подальші наукові пошуки вчених були зосереджені навколо вирішення проблеми оцінювання ефективності прийнятих рішень протягом певного періоду часу. В основу оновленого методу DEA було закладено використання так званих лагів (вагових показників для подолання проблеми запізнювання в часі соціальної віддачі від витрачених державних коштів) (Cook, 2014, с. 2-4). Застосування такої моделі DEA із використанням лагів дозволило дослідникам моделювати часовий період оцінювання ефективності прийнятих рішень.

Для оцінки динаміки ефективності регіональної соціальної політики ми пропонуємо застосовувати оновлену модель DEA і закладаємо певні вхідні (input) та вихідні (output) показники оцінки ефективності. Таким чином ми зможемо побудувати траєкторії регіонів у розрізі цих двох ознак. У своєму дослідженні ми будемо використовувати поняття «фінансово-економічна ефективність» на позначення вхідної ефективності витрат бюджетних коштів на певний регіон. Поняття «соціальна результативність» використовуватимемо на позначення вихідної ефективності, що демонструє, якою мірою регіон міг би збільшити соціальну результативність без збільшення витрат (Avkiran, 2011). За результатами отриманих показників ми зможемо класифікувати регіони України на певні групи (кластери) залежно від рівня та динаміки ефективності соціальної політики.

Метод DEA базується на принципі, що для конкретної досліджуваної проблеми існує певний набір можливостей, які складається з усіх допустимих комбінацій вхідних і вихідних даних. Тобто максимально допустиме значення для певного набору даних складатиме одиницю. Одиниця вважається ефективною, якщо вона споживає велику кількість вхідних ресурсів на велику кількість вихідних показників (принцип ефективності). Якщо певна політика є не ефективною (що також залежить від можливостей), необхідно відрегулювати розмір вхідних чи вихідних даних. Щоб знайти оптимальне рішення, як зменшити вхідні ресурси або збільшити вихідні показники, ми можемо скористатися методом DEA.

В основу методу DEA закладений механізм, який мінімізує «входи» та максимізує «виходи». Тобто закладається логіка ефективності, коли менші витрати ресурсів спричиняють більш продуктивні результати. Тому запропонований метод аналізу використовує поняття ефективність (efficiency) та результативність (effectiveness), оскільки саме від цього і залежить, наскільки продуктивною була політика в тій чи іншій сферах. Ефективність визначається як функція отриманих результатів і результатів, отриманих за рахунок використання ресурсів. Результативність описується з точки зору обсягу виконаної роботи та наскільки результати відповідають поставленим цілям. Таким чином, коли ми говоримо про ефективність певної політики, то повинні враховувати і вхідні ресурси та майбутні вихідні результати.

Метод DEA як інструмент оцінки ефективності є досить відомим і широко застосовуваним у західній науці, оскільки він використовується у різних сферах. Різні статистичні програми пропонують обраховувати DEA. Так, мова статистичного програмування R пропонує бібліотеку lpSolve для вирішення практичних завдань методом DEA (Hosseinzadeh, 2020).

Ключова ідея, закладається в основу застосування методу DEA, полягає у тому, що в публічній політиці основний ефект від державних витрат не є прямим, а навпаки накопиченим. Тобто необхідні систематичні вкладення протягом певного (здебільшого досить тривалого) періоду часу, щоб вони змогли створити необхідний вплив на результуючий показник. Тут прослідковується інвестиційний підхід до бюджетних витрат на певну сферу. Тому в сфері соціальної політики підсумкові показники за своєю природою здебільшого вже є «накопиченими», тобто інтегральними показниками. Найбільш показовий у цьому випадку показник - це середня очікувана тривалість життя при народженні, яка є результатом тривалого попереднього розвитку різних аспектів соціальної сфери. 


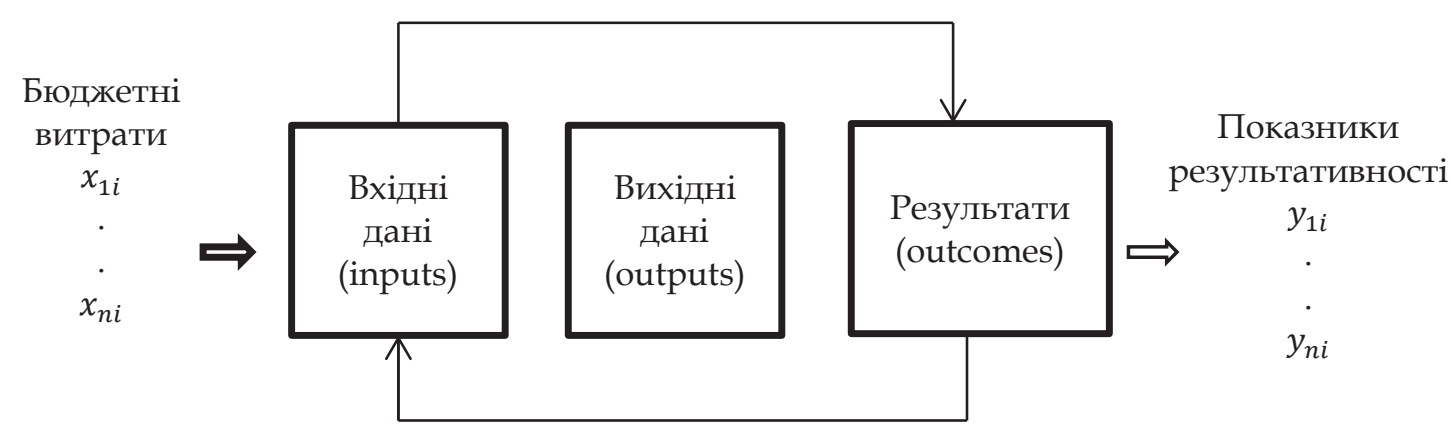

Рис. 1. Схема аналізу ефективності регіональної політики методом DEA Джерело: розроблено автором на основі (Charnes, 1994)

Застосування методу DEA передбачає побудову математичної моделі, де усі показники повинні бути вимірюваними (рис. 1). В основу побудови моделі покладено низку принципів. По-перше, показники результативності в соціальній сфері залежить від обсягу вкладених коштів та ефективності їх інвестування, тобто перетворення коштів у певний соціальний результат. По-друге, витрати на соціальну сферу характеризуються спадною віддачею, тобто на кожну додатково вкладену гривню ми будемо отримувати все меншу зміну показника результативності. Це легко можна простежити на простому прикладі. Наприклад, однакові додаткові витрати на освіту в Швеції дадуть набагато менший ефект порівняно з Україною. По-третє, вплив витрат на показники результативності може відбуватися із затримкою у часі.

Визначення залежності між якістю оцінок регіональної ефективності із затримкою у часі вираховується величиною лага, тобто підсумуванням бюджетних витрат за попередні роки. Величина лага може варіюватися від 0 (звичайний аналіз за методом DEA без підсумовування витрат) до 12 з кроком 2 (Cook, 2014). Практичне питання в цьому випадку полягає у тому, як вибрати величину часового лага в умовах реальної дійсності, коли істинне значення цієї величини невідомо (на відміну від експерименту).

Існує низка статистичних методів для оцінки часового лага, але усі вони вимагають тривалих часових радів, ніж ті, які можуть бути доступними. У такому випадку краще звернути увагу на набір статистичних показників, якими володіє дослідник, і прийняти відповідне рішення. Наприклад, якщо ми маємо дані, починаючи з 1991 року, тоді зможемо оцінити певний ефект від реалізації соціальної політики як мінімум з 1993 року. Звичайно, краще брати часовий лаг більший, але це залежить від статистичної інформації, якою ми володіємо. Можемо піти іншим шляхом, зокрема органи публічної влади можуть сформувати певний набір гіпотетичних об'єктів, які мають такі значення показників, що можуть бути прийняті в якості еталонних. Таким чином гіпотетичні об'єкти будуть певною мірою відображати межу ефективності, з якою можна зіставляти реальні досліджувані політики.

В емпіричну основу дослідження закладається статистична інформація, отримана через відкриті ресурси Міністерства розвитку громад та територій України, Міністерства соціальної політики України та Державної служби статистики України. Емпірична інформація охоплює п'ять ключових сфер соціальної політики: охорона здоров'я, освіта, безпека особистості, боротьба з бідністю і безробіттям та житлові умови населення. Для кожної зі сфер аналізу ми визначили відповідні індикатори ефективності як на вході, так і на виході.

Оскільки ми прагнемо виміряти ефект від витрачених бюджетних коштів у певній сфеpi, то будемо вираховувати накопичену суму бюджетних видатків за три роки (рис. 1). Наприклад, якщо ми хочемо отримати вхідний показник за 2020 рік, нам потрібно підсумувати бюджетні видатки на певну сферу за 2018, 2019 та 2020 роки. Далі цей показник необхідно зробити зваженим, враховуючи чисельність населення та індекс бюджетних витрат Міністерства фінансів України з метою забезпечення порівнянності регіонів та мінімізації ефектів географічної та соціально-економічної диференціації регіонів. 
Вхідні та вихідні дані для застосування Data Envelopment Analysis

\begin{tabular}{|c|c|}
\hline Вхідні дані (inputs) & Вихідні дані (outputs) \\
\hline $\begin{array}{c}\text { бюджетні видатки на охорону здоров'я } \\
\text { на душу населення }\end{array}$ & $\begin{array}{c}\text { рівень дитячої смертності } \\
\text { очікувана тривалість життя при народженні } \\
\text { рівень захворюваності первинним туберкульозом }\end{array}$ \\
\hline $\begin{array}{c}\text { бюджетні видатки на середню освіту } \\
\text { на душу населення }\end{array}$ & $\begin{array}{c}\text { частка учнів, які закінчили випускний клас } \\
\text { з атестатом про повну загальну середню освіту }\end{array}$ \\
\hline $\begin{array}{c}\text { бюджетні видатки на правоохоронні органи } \\
\text { на душу населення } \\
\end{array}$ & $\begin{array}{c}\text { кількість померлих внаслідок вбивства } \\
\text { у розрахунку на } 100 \text { тис. населення за рік }\end{array}$ \\
\hline $\begin{array}{l}\text { бюджетні видатки на житлово-комунальну } \\
\text { сферу, скориговані на чисельність населення }\end{array}$ & $\begin{array}{c}\text { питома вага обладнаної загальної площі } \\
\text { житлових приміщень } \\
\text { загальна площа ветхого та аварійного } \\
\text { житлового фонду }\end{array}$ \\
\hline $\begin{array}{c}\text { загальний обсяг витрат консолідованого } \\
\text { бюджету регіону на душу населення }\end{array}$ & $\begin{array}{c}\text { рівень безробіття за методологією МОП } \\
\text { частка населення з доходами нижче } \\
\text { прожиткового мінімуму }\end{array}$ \\
\hline
\end{tabular}

Джерело: складено автором

До вхідних показників оцінки ефективності соціальної політики ми відносимо бюджетні видатки на охорону здоров'я на душу населення; бюджетні видатки на середню освіту на душу населення; бюджетні видатки на правоохоронні органи на душу населення; бюджетні видатки на житлово-комунальну сферу, скориговані на чисельність населення й індекс бюджетних витрат, і загальний обсяг витрат консолідованого бюджету регіону на душу населення, скоригований на індекс бюджетних витрат (табл. 1).

До вихідних показників оцінки ефективності соціальної політики ми відносимо рівень дитячої смертності; очікувану тривалість життя при народженні; рівень захворюваності первинним туберкульозом; частку учнів, які закінчили випускний клас з атестатом про повну загальну середню освіту; кількість померлих внаслідок вбивства у розрахунку на 100 тис. населення за рік; рівень безробіття за методологією МОП; частку населення з доходами нижче прожиткового мінімуму; питому вагу обладнаної загальної площі житлових приміщень; загальну площу ветхого та аварійного житлового фонду (табл. 1).

Під час застосування методу DEA необхідно враховувати певні випадки. По-перше, варто звернути увагу на те, що приріст населення (це може бути актуальною проблемою для певних регіонів України) може досягатися як за рахунок підвищення народжуваності, так i за рахунок зниження смертності. По-друге, необхідно зважати на демографічну ситуацію, коли поряд із високою народжуваністю має місце й висока смертність або навпаки, коли при низькій смертності має місце низька народжуваність. Як у першому, так і у другому випадках зустрічаються регіони в Україні, де демографічна ситуація може набувати різних форм. Тому під час порівняння регіонів або під час вибору регіонів-еталонів необхідно враховувати тип демографічної ситуації. Бажано, щоб для регіону з першим типом демографічних процесів в якості еталонів слугували регіони, які розвиваються з цього ж типу. Для вибору шляху підвищення приросту чисельності населення слід скористатися моделями DEA, орієнтованими як на вхід, так і на вихід. У першому випадку будуть отримані конкретні кількісні рекомендації щодо зниження рівня смертності, а в другому - по збільшенню народжуваності.

Усі оцінки ефективності в DEA лежать в межах від 0 до 1 і відповідають структурі вихідних даних (Avkiran, 2011). Однак для негативних показників, таких як смертність чи захворюваність, необхідно значення вираховувати з одиниці. Це пов' язано із процедурою обрахунку, де змінні повинні зростати разом із показниками ефективності. Для таких показників як дитяча смертність, захворюваність на первинний туберкульоз, смертність від убивств, безробіття ми застосовуємо індекс, вираховуючи зважений показник з одиниці. Це пов'язано з тим, що, наприклад, рівень дитячої смертності не може розглядатися як «результат», тому такі показники необхідно трансформувати у рівень «дитячого виживання».

Після отримання показників ефективності (результативності) для кожної досліджуваної сфери необхідно провести обчислення зі зведення результатів у єдиний рейтинг ефективнос- 
ті регіонів України. В цьому випадку можна обрати один зі шляхів. У першому випадку можна обрахувати середнє арифметичне для кожного регіону України по усіх сферах соціальної політики. У другому випадку усі вихідні показники об'єднуються в так званий індекс розвитку регіону (в якості вхідного показника беремо бюджетні витрати регіону в перерахунку на душу населення з поправкою на індекс бюджетних витрат).

В Україні впроваджується політика відкритих даних, що дозволяє використовувати статистичну інформацію для побудови різних аналітичних методів. Нині найбільшим викликом для впровадження методу DEA для вимірювання ефективності політик $\epsilon$ наявність статистичної інформації в розрізі нового адміністративно-територіального поділу України. Оцінка ефективності діяльності територіальних громад матиме вирішальне значення для прийняття стратегічних рішень та ефективності видатків бюджету.

У роботі ми намагалися описати сучасний підхід до оцінки ефективності публічної політики на прикладі соціальної сфери. Незважаючи на переваги методу DEA-аналізу як інструменту оцінки ефективності прийнятих рішень, його застосування пов'язане з низкою методологічних труднощів. Щоб отримані результати не спотворювали інформацію про ефективність реалізації публічної політики, необхідно скоригувати результати вихідних даних. Найбільш простим методом є корекція оцінок, а більш складним - застосування регресійного аналізу для глибокого вивчення потенційних систематичних помилок.

Нашою метою було показати, як методологічний підхід, викладений у роботі, може допомогти в розумінні реалізації соціальної політики та прийнятті відповідних управлінських рішень.

\section{Лimepamypa}

Герасимчук 3.В. Регіональна політика сталого розвитку: методологія формування, механізми реалізації. Луцьк : Настир'я, 2001. С. 528.

Іртищева І.О., Гуріна О.В., Работін Ю.А. Методичні підходи до оцінки ефективності регіональної соціальної політики у контексті задоволення суспільних потреб. Вісник ХНАУ. Серія: Економічні науки. 2018. № 2. C. 412-422.

Макарова О.В. Соціальна політика в Україні. Київ : Інститут демографії та соціальних досліджень ім. М.В. Птухи НАН України, 2015. С. 244.

Садова У.Я. Регіональна соціальна політика в Україні: критерії оцінювання та показники ефективності. Демографія та соијальна економіка. 2008. № 1. С. 151-165.

Семів Л.К. Регіональна політика: людський вимір. Львів : ІРД НАН України, 2004. С. 392.

Avkiran N., Cooper W., Seiford M., Zhu J. Applications of data envelopment analysis in the service sector: Handbook on data envelopment analysis. NewYork : Springer, 2011.

Charnes A., Cooper W., Rhodes E. Evaluating program and managerial efficiency: anapplication of data envelopment analysis to program follow through. Management Science. 1981. Vol. 27. № 6. P. 668-697.

Charnes A., Cooper W., Lewin Y., Seiford M. Data Envelopment Analysis: Theory, Methodology, and Application. Boston : Kluwer Academ-ic Publishers, 1994.

Cook D., Tone K., Zhu J. Data Envelopment Analysis: Prior to Choosing a Model. Omega. 2014. Vol. 44. P. 1-4. Farhad Hosseinzadeh LotfiAli, Ebrahimnejad Mohsen, Vaez-Ghasemi, Zohreh Moghaddas. Data Envelopment Analysis with R. Springer, 2020. P. 236.

Golany B., Roll Y. Anapplication procedure for DEA. Omega. 1989. Vol. 17. P. 237-250.

\section{References}

Herasymchuk Z.V. (2001) Rehionalna polityka staloho rozvytku: metodolohiia formuvannia, mekhanizmy realizatsii [Regional policy of sustainable development: methodology of formation, implementation mechanisms]. Lutsk : Nastyria (in Ukrainian).

Irtyshcheva I.O., Hurina O.V., Rabotin Yu.A. (2018) Metodychni pidkhody do otsinky efektyvnosti rehionalnoi sotsialnoi polityky u konteksti zadovolennia suspilnykh potreb [Methodical approaches to assessing the effectiveness of regional social policy in the context of meeting social needs]. Bulletin of KhNAU. Series: Economic Sciences, Vol. 2, p. 412-422.

Makarova O.V. (2015) Sotsialna polityka v Ukraini [Social policy in Ukraine]. Kyiv : Instytut demohrafii ta sotsialnykh doslidzhen im. M.V. Ptukhy NAN Ukrainy (in Ukrainian).

Sadova U.Ya. (2008) Rehionalna sotsialna polityka v Ukraini: kryterii otsiniuvannia ta pokaznyky efektyvnosti 
[Regional social policy in Ukraine: evaluation criteria and performance indicators]. Demography and Social Economy, Vol. 1, p. 151-165.

Semiv L.K. (2004) Rehionalna polityka: liudskyi vymir [Regional policy: the human dimension]. Lviv : IRD NAN Ukrainy (in Ukrainian).

Avkiran N., Cooper W., Seiford M., Zhu J. (2011) Applications of data envelopment analysis in the service sector: Handbook on data envelopment analysis. New-York: Springer.

Charnes A., Cooper W., Rhodes E. (1981) Evaluating program and managerial efficiency: anapplication of data envelopment analysis to program follow through. Management Science, Vol. 27. № 6. P. 668-697.

Charnes A., Cooper W., Lewin Y., Seiford M. (1994) Data Envelopment Analysis: Theory, Methodology, and Application. Boston : Kluwer Academ-ic Publishers.

Cook D., Tone K., Zhu J. (2014) Data Envelopment Analysis: Prior to Choosing a Model. Omega, Vol. 44. P. 1-4. Farhad Hosseinzadeh LotfiAli, Ebrahimnejad Mohsen, Vaez-Ghasemi, Zohreh Moghaddas. (2020) Data Envelopment Analysis with R. Springer.

Golany B., Roll Y. (1989) Anapplication procedure for DEA. Omega, Vol. 17. P. 237-250.

\section{Анотація}

Аліксійчук О. В. Оцінювання ефективності регіональної соціальної політики: теоретикометодологічні моделі. - Стаття.

У статті розглянуто поняття ефективності регіональної політики на прикладі соціальної сфери, розкрито принципи оцінювання публічної політики на основі сучасного аналітичного методу аналізу.

Питання ефективності у виробленні публічної політики органами вдали набуває все більш важливого значення в умовах перманентних змін і процесу реформування адміністративно-територіального устрою. На територіальні громади покладено функцію вироблення та втілення політик у різних сфеpax, тому постає проблема ефективного використання бюджету громад. Органи публічної влади повинні шукати можливості для підвищення своєї ефективності. Реалізація соціальної політики держави на регіональному рівні повинна передбачати не лише ефективне використання ресурсів, а й забезпечувати належний розподіл отриманих результатів.

У статті актуалізується проблема у виробленні належної методології щодо оцінювання ефективності регіональної соціальної політики в Україні. Розкрито методологію кількісного визначення ефективності регіональної політики в соціальній сфері на основі аналітичного методу DEA (Data Envelopment Analysis). DEA є важливим інструментом у процесі прийняття рішень як органами державної влади, так і органами місцевого самоврядування, раціоналізації та оптимізації процесу публічної політики.

У статті ми намагалися показати, як метод DEA може працювати на реальних даних. Оцінка ефективності політики розглядається в якості як вхідної (input) інформації, так і вихідної (output). Ми можемо говорити про вхідну ефективність (efficiency) у тому випадку, коли регіон (або територіальна громада) міг би скоротити витрати без зміни соціального результату. Вихідна ефективність (effectiveness) демонструє, якою мірою регіон міг би збільшити соціальний результат без збільшення витрат. Тобто в основу моделі DEA закладений підхід оптимальності за Парето, який передбачає, що збільшення будь-якого показника не можливе без зменшення іншого показника. Формування та реалізація інституційних реформ передбачають перевлаштування системи таким чином, щоб збільшити ефект від одиниці вкладених ресурсів.

Ключові слова: публічна політика, ефективність, оцінювання, соціальна політика, DEA.

\section{Summary}

Aliksiychuk O. V. Evaluation of the effectiveness of regional social policy: theoretical and methodological models. - Article.

The article discusses the concept of effective regional policy for example social and discovered the principles of public policy evaluation based on modern analytical method of analysis.

The issue of efficiency in the development of public policy by the authorities is successfully becoming increasingly important in the context of permanent change and the process of reforming the administrative and territorial structure. In municipalities responsible function elaboration and implementation of policies in different sectors, and therefore there is a problem of effective use of the budget communities. Public authorities must look for opportunities to increase their efficiency.

Therefore, the implementation of social policy of the state at the regional level should provide not only the efficient use of resources, but also ensure the proper distribution of the results. The article highlights the problem of developing an appropriate methodology for evaluating the effectiveness of regional social policy in Ukraine. The methodology of quantitative determination of the effectiveness of regional policy in the social sphere on the basis of the analytical method DEA (Data Envelopment Analysis) is revealed. The DEA is an 
important tool in the decision-making process of both public authorities and local governments, streamlining and optimizing the public policy process.

In this article, we tried to show how the DEA method can work on real data. Evaluation of policy effectiveness is considered as both input and output information. We can talk about input efficiency in the case when the region (or local community) could reduce costs without changing the social outcome. Effectiveness shows the extent to which a region could increase its social outcome without increasing costs. That is, the DEA model is based on the Pareto optimality approach, which assumes that an increase in any indicator is impossible without a decrease in another indicator. The formation and implementation of institutional reforms involves the restructuring of the system in such a way as to increase the effect of a unit of invested resources.

Key words: public policy, efficiency, evaluation, social policy, DEA. 